\title{
How to organize secondary capital city regions: Institutional drivers of locational policy coordination
}

David Kaufmann and Fritz Sager

Contact information:

David Kaufmann

Postdoctoral researcher

University of Bern

KPM Center for Public Management

Schanzeneckstrasse 1

CH-3001 Bern, Switzerland

david.kaufmann@kpm.unibe.ch

www.kpm.unibe.ch

\author{
Fritz Sager \\ Professor of Political Science \\ University of Bern \\ KPM Center for Public Management \\ Schanzeneckstrasse 1 \\ CH-3001 Bern, Switzerland \\ fritz.sager@kpm.unibe.ch \\ www.kpm.unibe.ch
}

We study locational policy coordination in the metropolitan regions of secondary capital cities.

Secondary capital cities - defined as capitals that are not the prime economic city of their nation states - serve as the political center of their countries, however, they have to simultaneously find ways to develop their own regional economies. Locational policies, and the regional coordination thereof, aim at strengthening the economic competitiveness of metropolitan regions. We compare the metropolitan regions of Bern, Ottawa-Gatineau, The Hague, and Washington, D.C. and find that vertical institutional fragmentation, together with high local tax autonomy, largely explains the coordination and coherence of locational policies. Vertical institutional fragmentation creates an unlevel playing field fierce behavior in regional tax competition. These findings are troubling for secondary capital cities given their propensity to be located in fragmented metropolitan regions and because the imposed capital city-specific local tax autonomy constraints create an unlevel playing field. 


\section{Introduction}

Secondary capital cities (SCCs) are capitals that are not the primary economic city of their nation states. The traditional conceptualization of capitals clashes with growing pressures from economic globalization that push SCCs and their regional economies into interurban competition, just like any other metropolitan region. Originally, SCCs were established to serve the interests of the nation state and they were meant to abstain from commercial and economic aspirations. James Madison, the political theorist and fourth President of the United States (U.S.), argued in The Federalist Papers, no. 43 that the Federal District should be small in size and its development should be minimal (Hamilton, Madison, and Jay, 1982, 218). Nation states often create small local governing structures for SCCs, such as federal districts or city-states, in order to prevent second-tier political entities, such as states, provinces, or cantons, from having authority over the nation's capital. This practice increases the likelihood that the metropolitan regions of SCCs would span over multiple sub-national borders (Slack and Chattopadhyay 2009). In addition, smaller cities are often selected as capitals with the aim of uniting a country. Therefore, SCCs are prone to be located in areas of national tensions. These tensions tend to be mirrored by institutional fragmentation in the respective metropolitan region. As a consequence, policy-makers in SCCs who have started to formulate locational policies in order to be competitive - yet specialized - nodes in a globalized economy face particular challenges (Kaufmann 2018; Mayer, Sager, Kaufmann, and Warland 2018). In this article, we study the institutional drivers of locational policy coordination in the metropolitan regions of secondary capital cities.

The question is of growing practical relevance given the many relocation projects to move capital city functions such as the construction of Oyala as the new capital of Equatorial Guinea, the construction of Naypyidaw as the new capital of Myanmar, or the establishment of Putrajaya as the new Malaysian federal administrative capital. Especially former colonized nations want to break with their colonial ties by building a new capital city as a symbol of their independency 
(Moser 2010, 285). In fact, SCCs can be found on every continent. Famous examples of SCCs are located in Africa (e.g. Pretoria, Abuja), Asia (e.g. Jerusalem, Islamabad), Oceania (e.g. Wellington, Canberra), Europe (e.g. Berlin, The Hague), North America (e.g. Washington, D.C., Ottawa) and South America (e.g. Brasilia, Sucre). In most cases, SCCs are not infant capitals or capital cities that failed to develop properly. Instead, they were often deliberately chosen to exert a regulative, balancing, or symbolic role with the original idea that they should refrain from aspiring to become an economic powerhouse (Mayer, Sager, Kaufmann, and Warland 2016). However, given the growing international interurban competition, SCCs have been pressured to forgo their dependency on their nation state and to seek ways to become competitive in the international economic arena in their own right.

Locational policies incorporate a wide array of policies that aim to strengthen the competitiveness of a locality or a region. Locational policies in SCCs build on capital city functions because it is a local asset that is impossible for other cities in the national urban system to imitate (Kaufmann 2018; Mayer et al. 2018). Coordinating locational policies between jurisdictions in the entire metropolitan region has the potential to increase their effectiveness (Feiock, Steinacker, and Park 2009, 256). Coordination aims to ensure coherent policy-making by creating synergy effects and reducing confronting strategies within the region (Keating 1995). However, collective action dilemmas, such as high transaction costs or free riding, may hinder coordination (Ostrom 1990).

We apply a heuristic offered by Scharpf (1994) who conceptualized coordination as a welfaretheoretic concept that has the potential to achieve higher aggregated welfare in a region through aligned actions and strategically coordinated moves. We outline a pragmatic theoretical framework that employs two institutional explanatory factors that can explain the coordination of locational policies in the metropolitan regions of SCCs: institutional fragmentation within the metropolitan region and local tax autonomy. Policy coordination is a problem in capital city 
regions because of the high likelihood of regional institutional fragmentation and capital cities' specific restrictions on employing tax instruments (Slack and Chattopadhyay 2009, 305-306). We apply a theory-driven comparative case study design that compares four SCC metropolitan regions, namely, Bern, Ottawa-Gatineau, The Hague and Washington, D.C.

As we will outline during the course of this article, there are at least three reasons that make the coordination of locational policies in SCCs a relevant field of study. First, systematic research about SCCs is lacking. Second, the category of SCCs enables us to study specific regional economies, i.e. regional economies that are characterized by a strong public presence. Third, the academic literature often treats SCCs as an object of the nation state and thereby neglects the processes through which they are actively trying to increase their economic competitiveness. On a theoretical level, this article adds to recent debates about policy integration (e.g. Nordbeck and Steurer 2015) and policy coordination (e.g. Cejudo and Michel 2017), as well as to the still relevant debate about local tax competition (e.g. Keating 1995).

In the following section, we discuss SCCs and their locational policy efforts before turning to the theoretical framework that facilitates the analysis of coordination in SCCs. We find coordination of locational policies where there is both low vertical institutional fragmentation and low local tax autonomy. We suggest that an interaction effect is at work: Local tax autonomy has the greatest negative effect on coordination in metropolitan regions with high vertical institutional fragmentation because this fragmentation creates an unlevel playing field of tax competition. Furthermore, low vertical institutional fragmentation enables coordination as a process, whereas low tax autonomy enables locational policy coherence. Besides these institutional explanations, politics is also factors in when explaining the coordination of locational policies in SCCs. We discuss the practical implications of these findings in the conclusion. 


\section{Why secondary capital cities coordinate locational policies}

Campbell (2000) and Hall (2006) both offer categorizations of capital cities that differentiate between the political and economic role of a capital city. Hall (2006), for example, creates a category for global capitals, such as London and Tokyo, multi-functional capitals, such as Paris and Moscow and political capitals such as Washington, D.C. and Bern. Campbell (2000) distinguishes, among others, between the capital as dominant economic city in the nation state (such as Paris or Copenhagen) and the capital as secondary city (such as Ottawa or Canberra), and emphasizes the economic status and relative position of the capital within its respective nation's urban system. Whereas the political role is attached to the capital city status, "there is no rule that a political capital automatically attracts concomitant economic functions" (Hall 2006, 10). Building on Campbell (2000) and Hall (2006), we define a SCC as the capital city of a nation that has at least one other city that is economically more important to it than the capital city.

Capital city research stemming from political science mostly focuses on the political interactions between different levels of governments and on their conflicting role of serving the interests of the nation as a whole and those of its local residents (e.g. Harris 1995; Rowat 1973; Slack and Chattopadhyay 2009). Despite the "high interest in economic development efforts involving cooperation or collaboration among metropolitan jurisdictions" (Feiock, Steinacker, and Park 2009, 256), no study, thus far, tackles these questions in SCCs.

As in any other city, SCCs engage in interurban competition by formulating locational policies (Kaufmann 2018; Mayer et al. 2018). Examples of locational policies include: innovation policies that facilitate knowledge flows between crucial actors in a region, image building strategies that aim to craft a brand for the locality, the development of crucial infrastructure projects, strategies to attract firms and efforts to tap into upper-tier governmental funds (Kaufmann and Arnold 2018). Locational policies are formulated based on local assets, which 
explains why capital cities largely rely on their capital city status to formulate their locational policies (Kaufmann 2018). In international urban competition, the relevant competing units are not only the core cities, but also the metropolitan regions (Hall and Pain 2006). In the context of SCCs, this process of metropolization implies that jurisdictions in the metropolitan region also build their locational policies based on the capital city function.

\section{An institutionalist approach to policy coordination}

The phenomenon to be explained is the coordination of locational policies within the metropolitan regions of SCCs. Coordination is a process that takes place within an institutional setting (Koch 2013). Therefore, we develop an institutional theoretical framework to approach the coordination of locational policies in SCC regions. Because a comparative urban research agenda requires some degree of reductionism in order to prepare empirical observations for comparative assessment (Pierre 2005, 447), we develop a pragmatic theoretical framework with two institutional explanatory factors that should explain locational policies coordination. Drawing on the findings of an extensive comparison of eleven capital cities (Slack and Chattopadhyay 2009), institutional fragmentation in metropolitan regions and local tax autonomy were selected as the two institutional explanatory factors.

\section{Phenomenon to be explained: coordination}

Coordination is important for ensuring policy coherence within a metropolitan region. Coordination can be understood as a process, whereas the successful outcome of coordination can be labeled as policy coherence (Cejudo and Michel 2017; Nordbeck and Steurer 2015). We approach the coordination of locational policies within these regions by a heuristic offered by Scharpf: "[Coordination] is considered desirable whenever the level of aggregate welfare obtained through the unilateral choices of interdependent actors is lower than the level which could be obtained through choices that are jointly considered" (Scharpf 1994, 27). Similarly, the literature on institutional collective action emphasizes that local governments engage in 
coordination to capture spillover effects if the gains of coordination are likely to outweigh the transaction costs necessary to achieve it (Ostrom 1990).

Institutional collective action dilemmas arise because the decisions taken by one government impact other governments and their policies. Different coordination structures may address collective action dilemmas. Feiock (2013) differentiates coordination structures by their integration mechanisms and the scope of the policy fields these structures aim to coordinate. For example, councils of governments are based on statutes and incorporate only a small number of policy fields, such as public transportation, planning, and/or locational policies. Looser forms of coordination structures are informal networks or service contracts that often arise as alternatives to more institutionalized coordination bodies. Empirical studies highlight that effective coordination is often achieved through cooperative arrangements that stabilize the networks of policy-relevant actors, and not by institutionalized coordination structures (Sager 2005; Sager 2006).

Efforts to coordinate locational policies are often undertaken because there is a metropolitanwide common interest of locational promotion (Kübler and Piliutyte 2007, 365). Morgan (2014, 314) points out that one core motivation driving regional governance arrangements is to increase the economic competitiveness of the metropolitan region. Feiock, Steinacker, and Park (2009, 256) emphasize the large potential benefits of regional coordination in economic development policies, but they also add that "the transaction costs tend to be correspondingly high, making economic development one of the toughest cases for institutional collective action". Furthermore, the two step logic of firm-location - the first step consisting of a regional choice and the second, and later decision, consisting of a specific location within the chosen region (Cohen 2000) - aggravates the coordination of locational policies. The two-step logic of firm-location reveals the double logic of economic competition: Competition within a region is a threat for economic competitiveness in the competition between regions. 
We operationalize the coordination of locational policies within metropolitan regions with a heuristic mainly inspired by Fritz Scharpf (1994; 1997). Scharpf (1994) distinguishes between three manifestations of coordination. First, positive coordination describes the proactive search for synergies and for a common welfare that is higher than would be possible through individual action. The synergies of positive coordination should allow for the compensation of the losses of negatively affected actors. Second, negative coordination means the mere avoidance of contradictory action and redundancies without actively generating synergies. Third, and the worst case scenario for coordination, are beggar-my-neighbor behavior of different localities within a region (Keating 1995, 120). We consider beggar-my-neighbor behavior, as well as the absence of coordination, as a failure of coordination.

\section{Explanatory factor one: institutional fragmentation}

The coordination of policies between actors in a metropolitan region is conditioned by the mismatch between functional integrated regions and jurisdictional territories. Governing these institutionally fragmented metropolitan regions requires both vertical and horizontal coordination among governments (Hoffmann-Martinot and Sellers 2005). Morgan (2014) argues that institutional fragmentation in metropolitan regions, i.e. the boundaries of administrative areas, is a considerable barrier to coordinated locational policies.

In this article, we distinguish between the horizontal and vertical dimensions of institutional fragmentation. The horizontal dimension represents the quantity of local governments that are present in a metropolitan region. We expect that more independent local jurisdictions in a metropolitan region hinder coordination because such a setting increases collective actions problems, such as transactions costs or opportunities to free ride. The vertical dimension expresses the presence of upper-tier governmental entities in a metropolitan area. Metropolitan areas may be integrated within a single state, province or canton, or metropolitan areas may be divided by multiple upper-tier governmental entities. We expect that vertical institutional 
fragmentation hinders coordination because, in such a case, different local governments belong to different lines of political authority.

Vertical institutional fragmentation in particular is often an issue in SCCs for two reasons. First, the cities chosen as capitals are often selected due to their prospect of uniting a country and are thus located in areas of national tensions. A good example is the choice of Ottawa to bridge Anglophone and Francophone Canada. Second, specific governing structures (e.g. federal districts) have been created for some capitals that are relatively small-scale and which only cover the core city of the capital region. For example, the metropolitan region of Washington, D.C. is highly fragmented as it incorporates the District of Columbia and three additional states (Virginia, Maryland and West Virginia), which are in turn home to various local jurisdictions.

\section{Explanatory factor two: local tax autonomy}

The national tax system determines a jurisdictions' ability to raise income (Page and Goldsmith 1987, 7). The degree of local tax autonomy can be operationalized (1) by the availability of tax instruments and (2) by the proportion of all national tax revenue that is collected at the local level. High local autonomy means that local governments have a variety of tax instruments at hand, such as personal income tax, corporate income tax and property tax on land and real estate. In a low local tax autonomy context some of these tax instruments are the prerogative of higher-tier political entities. To compensate for these limitations on local tax instruments, substantial public money is transferred from higher-tier political entities to finance local budgets (Goldsmith 2012, 137). The proportion of all national tax revenue collected at the local level is a straightforward measurement of local tax autonomy (Sellers and Lidström 2007, 616618). The availability of tax instruments and the proportion of tax revenue at the local level should be positively correlated.

We expect local governments with far reaching tax rights to take full advantage of their competences. High local tax autonomy enables them to lower taxes or award tax incentives. In 
a high tax autonomy setting, local governments have powerful incentives to compete against each other to attract residents, firms and other taxable capital (Keating 1995). Thus, tax competition is likely to trump locational policy coordination. Hence, we expect that high local tax autonomy constrains the coordination of locational policies, whereas low tax autonomy enables coordination.

Capital city-specific local tax autonomy constraints are important in the context of this article. For example, Washington, D.C. as the U.S. Federal District does not enjoy the same tax rights as other U.S. states. Washington, D.C. cannot tax commuters that work in the District of Columbia but reside outside of it. Furthermore, the local tax base of capital cities is restricted because of tax exemptions on property belonging to the national government, as well as on property belonging to foreign governments (such as embassies or consulates). Unsurprisingly, this property tax exemption has the most financial consequences in capital city regions. These tax losses are severe for local budgets that rely on property tax as the most important local tax instrument, such as in Ottawa or The Hague.

\section{Propositions}

The two explanatory factors, together with the operationalization of coordination, result in four possible configurations of propositions, which are described in Figure 1. In line with the institutionalist tradition, we distinguish between enabling and constraining institutional settings. Following Scharpf $(1997,36)$, we expect that "political interaction is driven by the interactive strategies of purposive actors operating within institutional settings that, at the same time, enable and constrain these strategies". 
FIGURE 1

Propositions

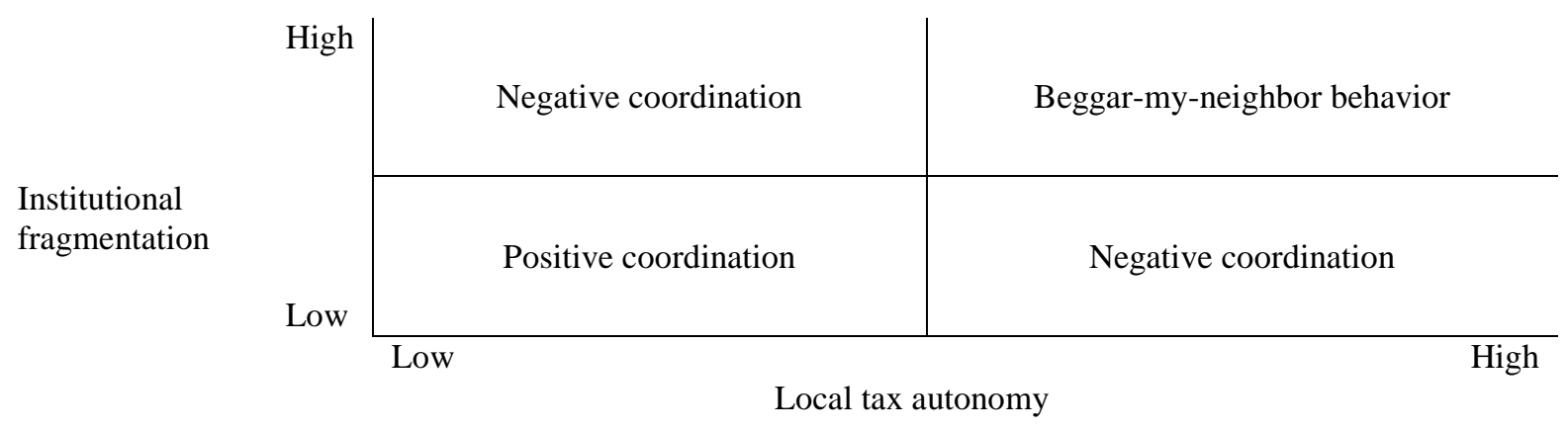

\section{Research design}

We employ a comparative multiple case study design that includes four SCC regions in OECD countries, namely Bern, Ottawa-Gatineau, The Hague and Washington, D.C. Following a 'most similar systems'-design (Przeworski and Teune 1970), the four cases constitute a theory-driven sample in order to "maximize the variance of the independent variable[s] and to minimize the variance of the control variables" (Lijphart 1975, 165). This enables the research design to juxtapose a cross-case analysis with a within-case analysis of causal mechanisms that allows for reliable causal inferences (Collier and Brady 2010, 10).

Since the study of capital cities is inherently a study of exceptions (Campbell 2000, 22), we restrict ourselves to four SCCs in OECD countries. ${ }^{1}$ This enables us to control for some of the economic and political context while allowing for variance in the two proposed explanatory factors.

Figure 2 shows the maps of the four metropolitan regions under scrutiny. The maps illustrate the vertical and horizontal institutional fragmentation in the four metropolitan regions. The metropolitan region of Bern consists of 29 municipalities that all belong to the Canton of Bern.

\footnotetext{
${ }^{1}$ There are ten SCCs in the 34 OECD countries: Canberra, Australia; Ottawa, Canada; Berlin, Germany; Jerusalem, Israel; Rome, Italy, The Hague, The Netherlands; Wellington, New Zealand; Bern, Switzerland; Ankara, Turkey; Washington, D.C., United States.
} 
The metropolitan region of Ottawa-Gatineau consists of 15 cities, townships and municipalities and is divided at its very core between the provinces of Ontario and Quebec. In the metropolitan region of The Hague, all six local governments belong to the province of South Holland. The metropolitan region of Washington, D.C. consists of 23 counties and cities, as well as the District of Columbia, and spans over three states in addition to the District of Columbia. A list of the local jurisdictions in each metropolitan region can be found in the appendix. 
FIGURE 2

Maps of the metropolitan regions of the selected SCCs

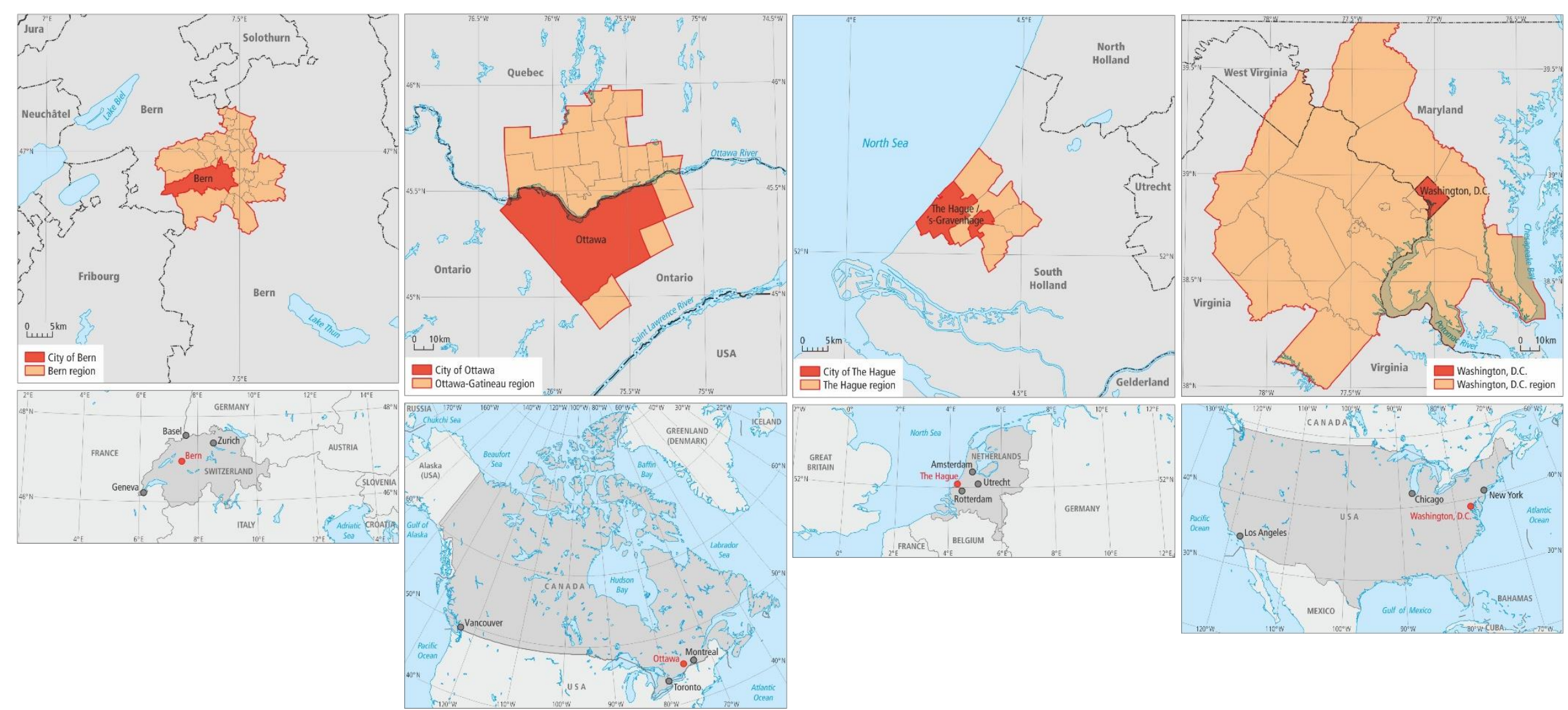

Source: own illustration 
Information on the second explanatory factor, local tax autonomy, was collected through a review of local governments' availability of tax instruments during the field studies and by consulting the OECD Fiscal Decentralization Database (OECD 2014) that measures the proportion of tax revenue collected at the local level. The U.S. and Switzerland both have high tax autonomy - around $15 \%$ of all tax revenue is raised on the local level. In Switzerland, local governments are allowed to levy, among others, personal income tax, corporate income tax and property tax. In the U.S., state law determines the availability of local governments' tax instruments. In Canada, local governments raise $9 \%$ of all taxes, and they are only allowed to collect property tax. In the Netherlands, local governments only raise $3.6 \%$ of all taxes, and they are only allowed to collect property tax.

Table 1 summarizes the four cases. Figure 3 illustrates the variances of the cases in the two explanatory factors and identifies which case fits to which proposition in Figure 1. 
TABLE 1

Summary of selected cases

\begin{tabular}{|c|c|c|c|c|c|}
\hline Type of factor & Factor & Bern & $\begin{array}{l}\text { Ottawa- } \\
\text { Gatineau }\end{array}$ & The Hague & $\begin{array}{l}\text { Washington, } \\
\text { D.C. }\end{array}$ \\
\hline Control factor & $\begin{array}{l}\text { Type of capital } \\
\text { city }\end{array}$ & $\begin{array}{l}\text { Secondary } \\
\text { capital city }\end{array}$ & $\begin{array}{l}\text { Secondary } \\
\text { capital city }\end{array}$ & $\begin{array}{l}\text { Secondary } \\
\text { capital city }\end{array}$ & $\begin{array}{l}\text { Secondary } \\
\text { capital city }\end{array}$ \\
\hline Control factor & Type of country & $\begin{array}{l}\text { Western } \\
\text { OECD country }\end{array}$ & $\begin{array}{l}\text { Western } \\
\text { OECD } \\
\text { country }\end{array}$ & $\begin{array}{l}\text { Western } \\
\text { OECD country }\end{array}$ & $\begin{array}{l}\text { Western } \\
\text { OECD } \\
\text { country }\end{array}$ \\
\hline Context factor & $\begin{array}{l}\text { Inhabitants of } \\
\text { capital city }\end{array}$ & $131 ' 554$ & $957 ' 148$ & $514 ’ 861$ & $672^{\prime} 228$ \\
\hline Context factor & $\begin{array}{l}\text { Inhabitants of } \\
\text { metropolitan } \\
\text { region }\end{array}$ & $314^{\prime} 223$ & 1’332’001 & $838^{\prime} 015$ & $6^{\circ} 097^{\circ} 684$ \\
\hline Context factor & State type & Federal state & Federal state & $\begin{array}{l}\text { Decentralized } \\
\text { unitary state }\end{array}$ & Federal state \\
\hline $\begin{array}{l}\text { Explanatory factor } \\
\text { one }\end{array}$ & $\begin{array}{l}\text { Institutional } \\
\text { fragmentation } \\
\text { - Horizontal } \\
\text { - Vertical }\end{array}$ & $\begin{array}{l}\text { Ambivalent } \\
\text { - High } \\
30 \text { local } \\
\text { governments } \\
\text { - Low } \\
\text { All local } \\
\text { governments } \\
\text { within the } \\
\text { same canton }\end{array}$ & $\begin{array}{l}\text { Rather high } \\
\text { - Rather low } \\
15 \text { local } \\
\text { governments } \\
\text { - High } \\
\text { Provincial } \\
\text { boundaries at } \\
\text { the very core }\end{array}$ & $\begin{array}{l}\text { Low } \\
\text { - Low } \\
6 \text { local } \\
\text { governments } \\
\text { - Low } \\
\text { All local } \\
\text { governments } \\
\text { within the } \\
\text { same province }\end{array}$ & $\begin{array}{l}\text { High } \\
\text { - High } \\
24 \text { local } \\
\text { governments } \\
\text { - High } \\
\text { Three states } \\
\text { and the } \\
\text { District of } \\
\text { Columbia }\end{array}$ \\
\hline $\begin{array}{l}\text { Explanatory factor } \\
\text { two }\end{array}$ & $\begin{array}{l}\text { Local tax } \\
\text { autonomy } \\
\text { - Availability of } \\
\text { tax instruments } \\
\text { - Share of local } \\
\text { tax revenue } \\
\end{array}$ & $\begin{array}{l}\text { High } \\
\text { - Personal } \\
\text { income tax, } \\
\text { corporate } \\
\text { income tax, } \\
\text { property tax }\end{array}$ & $\begin{array}{l}\text { Rather low } \\
\text { - Property tax }\end{array}$ & $\begin{array}{l}\text { Low } \\
\text { - Property tax }\end{array}$ & $\begin{array}{l}\text { High } \\
\text {-Property tax; } \\
\text { Personal } \\
\text { income tax, } \\
\text { and sales and } \\
\text { use tax } \\
\text { determined by } \\
\text { state law } \\
\text { - } 15.9 \%\end{array}$ \\
\hline $\begin{array}{l}\text { Phenomenon } \\
\text { to be explained }\end{array}$ & $\begin{array}{l}\text { Coordination of } \\
\text { locational } \\
\text { policies }\end{array}$ & $?$ & $?$ & $?$ & $?$ \\
\hline
\end{tabular}

Source: See the appendix for population data (all from 2015) and the definitions of the metropolitan regions. The information on the share of local tax revenue was obtained from the OECD's 2014 tax autonomy indicators (data from 2011). 
FIGURE 3

Variances of the cases in the two explanatory variables

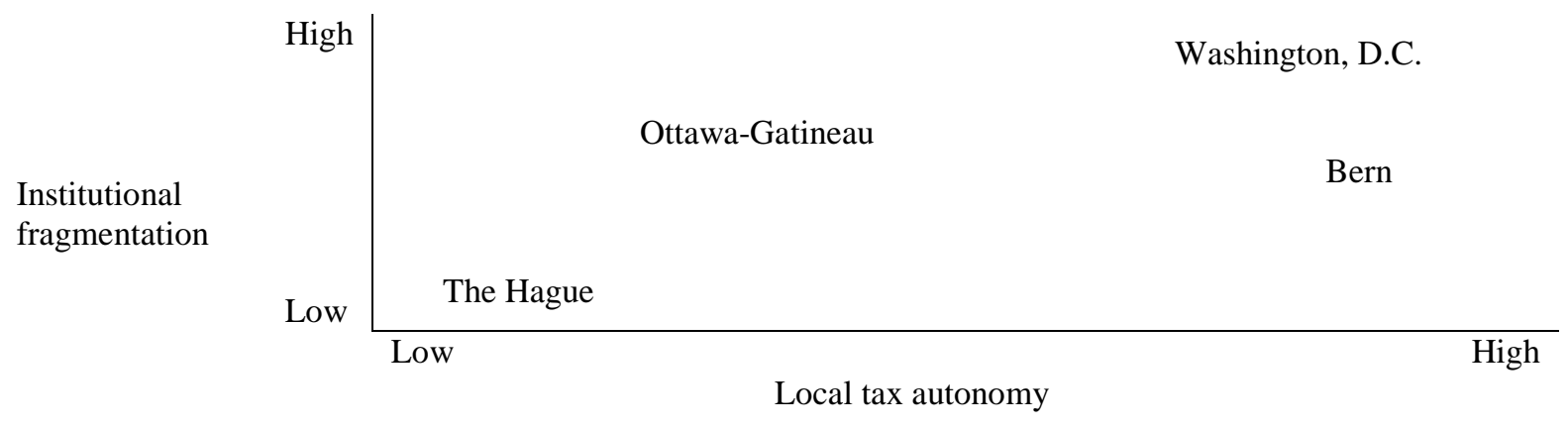

Note: Distances only serve illustrative purposes and do not imply observed values

We ensured that we triangulated the data throughout the entire data collection process. The backbone of this article consists of 91 semi-structured, in-person interviews with 103 relevant decision-makers in the four SCCs selected. The interview questions covered the full range of possible locational policies and their coordination. The interview partners were carefully selected to ensure sufficient variety within the cases and consistency between them. Some of the interviewees include high-profile actors, such as the mayor of Bern, the State Advocate of the Netherlands (Landsadvocaat), the Executive Director of the Metropolitan Washington Council of Governments, and the Chief Executive Officer (CEO) of Invest Ottawa. The interviews took place during the three-month field study in all four SCCs between summer 2014 and summer 2015. We took full advantage of existing contacts and networks to obtain access to interview partners, data and documents. The interviewees have authorized the use of their statements in the case studies. Table 2 summarizes the interviews. A list of interview partners is provided in the appendix (see Table A1). 
TABLE 2

Summary of the interviews in all four SCCs

\begin{tabular}{l|c|c|c|c|c} 
Type of interviewee & Bern & $\begin{array}{l}\text { Ottawa- } \\
\text { Gatineau }\end{array}$ & The Hague & $\begin{array}{l}\text { Washington, } \\
\text { D.C. }\end{array}$ & Total \\
\hline $\begin{array}{l}\text { - Public Official } \\
\text { (local, second-tier and } \\
\text { national government) }\end{array}$ & 6 & 5 & 9 & 8 & $\mathbf{2 8}$ \\
\hline $\begin{array}{l}\text { - Economic development } \\
\text { agent }\end{array}$ & 3 & 6 & 4 & 4 & $\mathbf{1 7}$ \\
$\begin{array}{l}\text { - Regional coordination } \\
\text { agent }\end{array}$ & 7 & 6 & 5 & 8 & $\mathbf{2 6}$ \\
\hline $\begin{array}{l}\text { - Business actor } \\
\text { - Private interest group }\end{array}$ & 3 & 4 & 6 & 7 & $\mathbf{2 0}$ \\
\hline $\begin{array}{l}\text { - Expert } \\
- \text { Academic }\end{array}$ & $\mathbf{1 9}$ & $\mathbf{2 1}$ & $\mathbf{2 4}$ & $\mathbf{2 7}$ & $\mathbf{9 1}$
\end{tabular}

In the following sections, we test our propositions in the four cases under scrutiny. All four case studies are presented in the same way: first, we briefly present the case's context, then we outline the phenomenon to be explained and we conclude by outlining the explanatory factors that were found.

\section{Bern}

We expected to observe negative coordination because of ambiguous institutional fragmentation, i.e. high horizontal institutional fragmentation, low vertical institutional fragmentation and high local tax autonomy. The findings do not support our proposition because there is no coordination of locational policies in Bern. This absence of coordination may be explained by political explanations, such as the fear of ceding local autonomy and a political divide between the city and the agglomeration's municipalities.

Although Bern was once very powerful - at its pinnacle (1500-1800) it was the largest European city-state north of the Alps - it has consistently lost ground to other economic powerhouses of the Swiss urban system. When judged by various demographic and economic measures, Bern stands in the shadows of the much larger, and economically more prosperous, Swiss cities of Zurich, Geneva-Lausanne and Basel (Kaufmann et al. 2016). Business actors believe that the 
absence of coordination in Bern's metropolitan region is one of the major causes for Bern's decreasing importance (Interviews: Bucher, Gasche).

Municipalities in Bern's metropolitan region are embedded in a council of government organization called the Regional Conference (Regionalkonferenz Bern-Mittelland), which is mostly active in the fields of public transport infrastructure and land-use planning. There is a subdivision of the Regional Conference, the Sub-Conference Economy (Teilkonferenz Wirtschaft), which is responsible for coordinating economic policies. However, neither the Regional Conference, nor the Sub-Conference, is able to foster profound locational policy coordination. A politician explains the weaknesses of the Regional Conference:

The regional conference has too few responsibilities and it is limited in its effectiveness. I see the Regional Conference and its sub-conference as a paper tiger. The important political decisions are still being made in the municipalities (Interview Rytz).

Similarly, van der Heiden $(2010,45)$ posits that jurisdictions in the Bern region are not interested in coordinating their international strategies. Additionally, there is moderate tax competition between municipalities for attracting residents. When it comes to attracting firms, both the mayor of Bern and the economic development officer of Köniz - the second largest municipality in the metropolitan region of Bern - agree that it is beneficial for their municipalities if a firm settles anywhere in the metropolitan region (Interviews: Pfyl, Tschäppät). To conclude, although regional coordination structures exist, we did not find coordinated locational policies in the metropolitan region of Bern.

The interviewees point to three reasons that may explain the absence of coordination and the competition for attracting residents. First, due to their high local tax autonomy, municipalities moderately compete for residents (Interviews: Gasche, Rytz, P. Stämpfli, Walter). The tax instruments available in the municipalities, such as taxing personal income, makes residents an important tax base. For example, personal income tax in the city of Bern makes up $42.5 \%$ of 
the revenue of the local budget (Federal Finance Administration 2016). Second, there is resistance towards anything that could potentially constrain municipal autonomy (Interviews: Rytz, Gasche). This is well documented by van der Heiden (2010) who observed that decisionmakers in agglomeration municipalities are unwilling to restrict their political autonomy in favor of collective actions. Third, the interviewees point to a partisan divide that exists between the agglomeration's municipalities and the core city. Whereas the city of Bern is a political stronghold of the Social Democrats and the Green Party, the municipalities in the agglomeration are dominated by moderate-right and conservative-right parties (Interviews: Bratschi, Gasche, Rytz).

\section{Ottawa-Gatineau}

We expected to find negative coordination due to institutional fragmentation in the heart of the metropolitan region and low local tax autonomy. However, as in Bern, the coordination of locational policies is absent in the metropolitan region of Ottawa-Gatineau. Thus, the findings do not support our proposition. This case study reveals the strong influence of the Canadian provinces and the impact of the region's urban/rural divide.

Ottawa was a farmer and lumber town before it was chosen as Canada's capital in 1867. After the two World Wars, Ottawa's dominant economic sector changed from the primary sector (forestry) to the public sector. From the mid-1990s to the early 2000s, Ottawa's economy boomed thanks to its innovative high-tech sector. The burst of the dot.com bubble in the early 2000s made the public sector the region's largest employer again and marked the sharp end of Ottawa's short economic rise. The collapse of the high-tech sector put locational policies high on Ottawa's political agenda (Andrew and Doloreux 2014, 142-144).

Ottawa amalgamated with eleven smaller Ontarian municipalities in 2001. The neighboring Quebecois city of Gatineau was formed in 2002, also through an amalgamation of five municipalities. As a consequence, the cities of Ottawa and Gatineau became powerful and 
distinctly urban in comparison to their rural neighboring municipalities. Since 1968, the federal government has attempted to enhance its presence in Quebec by shifting federal offices and cultural facilities across the river to Gatineau. However, neither the amalgamation, nor the federal presence in Gatineau has encouraged the coordination of any policies between Ottawa and Gatineau (Interviews: Chattopadhyay, Lapointe). Thus, "people are talking about Ottawa and Gatineau as the two solitudes" (Interview La Flamme).

The economic development agencies in Ottawa and Gatineau, Invest Ottawa and Développement économique - CLD Gatineau, do not coordinate their locational policies with their counterparts on the other side of the Ottawa River. The same is true for economic interest organizations like the Chambers of Commerce or the Business Improvement Districts (Interviews: Faris, Normand, Sudds). However, we did not find competition or beggar-myneighbor behavior.

The absence of coordination can largely be explained by vertical institutional fragmentation. It starts with very basic problems: Neither local government can engage in activities that would mean spending one jurisdiction's taxpayers' dollars on a project that would uniquely benefit the other jurisdiction. This vertical institutional fragmentation also includes different political systems and issues regarding Quebec's status within Canada (Interviews: Paquet). We can see Canada's very political struggles manifest themselves in its capital city region. The political dilemma surrounding Ottawa-Gatineau leads Gilles Paquet to conclude that "Ottawa is probably the hardest capital city region to govern" (Interview Paquet). The few tax instruments available to Canadian municipalities prevent an outbreak of tax competition over firms or residents. The fragmentation in the metropolitan region is not limited to the provincial borders. The two core municipalities - Ottawa and Gatineau - see no need to cooperate with the remaining municipalities in their respective provinces. This can be explained by geography and, more precisely, by the urban/rural divide. The economic bases of the two core municipalities 
and the remaining rural municipalities are so diverse that coordinating locational policies does not make much sense.

\section{The Hague}

We expected to find positive coordination of locational policies because of low institutional fragmentation and low local tax autonomy. The findings support our proposition. In addition, The Hague's location in a polycentric metropolitan region explains positive coordination in its metropolitan region.

The Hague is deeply embedded in the huge polycentric metropolitan region called Randstad. Together with Amsterdam, Rotterdam and Utrecht, The Hague is one of the four urban centers that make up the Randstad. The Hague is mostly described and studied in the context of its international organizations (e.g. van Krieken and McKay 2005), however, it also hosts most national government organizations, such as the Dutch Parliament, the Cabinet of the Netherlands and the Supreme Court of the Netherlands. Thus, the presence of the public sector provides The Hague with a distinct economic profile that is complementary to the other major cities of the Randstad (Meijers, Hoogerbrugge, Louw, Priemus, and Spaans 2014, 92).

Until its termination at the end of 2014, the City-Region Haaglanden served as the political coordination structure for environmental issues, spatial planning, and locational policies. At the beginning of 2015, the two City-Regions of Rotterdam and Haaglanden merged into the Metropolitan Region of Rotterdam The Hague (MRTH). This new coordination structure captures 2.2 Mio inhabitants, consists of 23 municipalities, employs around 100 staff members and is an economic region of international importance. The establishment of the MRTH was initialized by the mayors of Rotterdam and The Hague in 2010 (Interviews: Meijers, Vorkurka \& Nijhof, J. de Vries). The MRTH is a powerful player, which is exemplified by the Dutch government's decision to allocate its transportation funds directly to the MRTH (Meijers et al. 
2014, 93). Beyond public transportation, the MRTH seeks to strengthen its economic competitiveness by coordinating locational policies (Interview Vokurka \& Nijhof).

There are three reasons that can explain the positive coordination of locational policies in the case of The Hague. First, all of the municipalities that cooperate within the MRTH belong to the province of South Holland (Zuid-Holland). The establishment of the MRTH was a strategic move carried out by Rotterdam and The Hague to gain more autonomy from the province of South Holland (Interviews: Meijers, Schuttenbeld). The economic development director of the MRTH explains the intention:

We have to redefine the relationship with the province. The hierarchical structure of the three state levels does not match the realities anymore. The mayors of the big four cities have a direct line to the Prime Minister (Interview Vorkurka \& Nijhof).

Indeed, the provinces are the least powerful of the three state levels in the Netherlands and the major Dutch cities "often view the provinces as unwelcome representatives of the smaller municipalities that surround them" (Andeweg and Irwin 2014, 212-213). As a consequence, the MRTH was initiated by the two big cities with noticeably less political commitment from the mayors of the smaller municipalities. Second, low local tax autonomy helps the coordination of locational policies. Rotterdam and The Hague do not primarily see each other as competitors, but rather as complementary parts (Interview van Loon). The municipalities still compete to acquire firms. However, compared to cases with high local tax autonomy, the competition is very transparent and is mostly based on complementary clusters of firms, and there is a gentlemen's agreement that forbids the so-called poaching of firms (Interviews: Oliver, van Vondel \& M. de Vries, Vorkurka \& Nijhof). Third, the special polycentric setting of the Randstad makes coordination very attractive because it provides ample opportunities to 'borrow size' (Burger, Meijers, Hoogerbrugge, and Tresserra 2015). Only together with other cities in the Randstad is The Hague able to provide a sufficient critical mass to support a wide range of 
metropolitan functions and to be competitive in interurban competition (Meijers et al. 2014, 98-99).

\section{Washington, D.C.}

We expected to find beggar-my-neighbor behavior between the jurisdictions in this metropolitan region because of its high institutional fragmentation and high local tax autonomy. The findings support our proposition.

Establishing the capital city in Washington, D.C. in 1800 was an intentional move to insulate the newly founded republic's federal government from the influence of any state or commercial center (at that time New York and Philadelphia) (Ghandi, Yilmaz, Zahradnik, and Edwards 2009, 271). The whole metropolitan region has experienced an impressive history of economic development due the presence of the federal government. Steven Fuller, a long time economic observer of the region, sees a "direct correlation between the regions' GDP and federal spending" (Interview Fuller).

The Greater Washington Initiative (GWI), a public-private partnership mostly funded by the different jurisdictions of the region, was tasked until 2010 with coordinating locational policies in the metropolitan region. Whereas the smaller jurisdictions appreciated the GWI's standardized services, the larger jurisdictions (such as Arlington, Alexandria, Fairfax, or Montgomery) pursued their own locational policy activities while they were part of the GW (Interviews: Hawkins and Landrum, Richmond and Winn, White). In 2010, some larger jurisdictions stopped funding the initiative, which led to the dissolution of the GWI in that same year. Currently, two organizations remain to tackle the coordination of locational policies. One is the informal network Commission of Economic Development Officials (CEDO), which brings the different jurisdictions' economic development agents together. However, the purpose of the CEDO is to share information and best practices, and not to coordinate policies (Interview Boyer). The other organization is the Metropolitan Washington Council of Governments 
(MWCOG), which focuses on transportation, land-use planning and environmental issues. The MWCOG seeks to coordinate some locational polices, for example the region's cyber security activities, however, it struggles to obtain the jurisdictions' support in this policy area (Interview Bean). Neither the CEDO nor the MWCOG have been able to fill the vacuum that resulted following the termination of the GWI.

All interviewees agree that there is fierce within competition regarding firm acquisition and the attraction of taxpayers in the Washington, D.C metropolitan region. (Interviews: Boyer, Hawkins and Landrum, White, Richmond and Winn, Zipper). There is a so-called non-poaching agreement between the jurisdictions in the metropolitan region dating back to the CEDO's predecessor organization of the CEDO (Interviews: Boyer, Richmond and Winn), however, the jurisdictions have been unable to agree upon a new non-poaching agreement under the auspice of the GWI (Interview White). Even though poaching has been condemned in many interviews, the non-poaching agreement only has a limited impact because firms are aware of the obvious competition and they approach the different jurisdictions directly or via brokers (Interviews: Hawkins and Landrum, Loescher, Zipper). A former District of Columbia Director of Business Development and Strategy is very critical regarding the regional competition:

This non-poaching agreement has no impact on the ground. It is just a phrase. We have a severe competition in the Washington, D.C. region that is almost a race-to-the bottom. This competition dynamic is counterproductive for the whole region and the lack of regional policy coordination is one of the biggest weaknesses of the region (Interview Zipper).

The interviewees attribute within competition to the interaction of the two proposed explanatory factors. First, the Washington, D.C. region is a typical case of high vertical institutional fragmentation. Its core, the District of Columbia, only accounts for about $10 \%$ of the population. Virginia, West Virginia, Maryland, and the District of Columbia have different political histories and institutions (Interviews: Fuller, Hawkins and Landrum). The District of Columbia is a special political entity, as it has to fulfil the functions of a state as well as those of a county, 
a city and a school district, without the authority to raise revenue in the way all other states are allowed to (Ghandi et al. 2009; Harris 1995). This high institutional fragmentation makes regional coordination complicated (Interviews: Fuller, Young and Wolman).

Second, competition in this metropolitan region can be explained by the interaction of its vertical institutional fragmentation with its high local tax autonomy. Each state has different tax rules and each jurisdiction has a different tax rate. This high local tax autonomy enables jurisdictions to offer tax benefits and other financial incentives that make the whole economic dynamic very competitive (Interview Zahradnik). For example, jurisdictions in Virginia are not allowed to levy personal or corporate income tax. However, these Virginian jurisdictions are very competitive and aggressive and offer various other incentives to firms, such as reduced real estate rents and property tax breaks. Jurisdictions in Maryland are allowed to levy piggyback taxes on personal income, which encourages them to prioritize the creation of favorable living conditions for their taxpayers (Interviews: Buchanan, Richmond and Winn). The District of Columbia itself has a very different tax setting, since it is not allowed to levy the so-called 'Commuter Tax' on the income of non-residents that work in the District of Columbia, and federal property is tax exempt. In sum, the interaction of these two explanatory factors creates an unlevel playing field that fuels competition between the jurisdictions. Chuck Bean, the Executive Director of the MWCOG, sums it up nicely: "We can't change anything about the institutional fragmentation and the different tax systems. So we have to accept that and try to work around it" (Interview Bean).

\section{Discussion}

The comparison of our case studies reveals insights with regard to both our explanatory factors as well as to additional explanatory factors beyond the narrow institutional focus of this article. The findings of the four case studies are summarized in Table 3. In general, we only found the coordination we proposed when both explanatory factors either enable or constrain 
coordination. Mixed directions of influence (high institutional fragmentation and low tax autonomy, or vice versa) do not lead to negative coordination. Instead, they result in an absence of coordination that can be considered to be a form of coordination failure.

\section{TABLE 3}

\section{Findings of the case studies}

\begin{tabular}{l|l|l|l} 
Cases & $\begin{array}{l}\text { Phenomenon to be } \\
\text { explained }\end{array}$ & Explanatory factors & Proposition \\
\hline Bern & Absence of coordination & $\begin{array}{l}\text { - High local tax autonomy } \\
- \text { Fear of ceding local autonomy } \\
- \text { Partisan divide between the core and the } \\
\text { agglomeration }\end{array}$ & $\begin{array}{l}\text { Not } \\
\text { supported }\end{array}$ \\
\hline $\begin{array}{l}\text { Ottawa- } \\
\text { Gatineau }\end{array}$ & Absence of coordination & $\begin{array}{l}\text { - High vertical institutional fragmentation } \\
\text { - Low local tax autonomy } \\
\text { - Urban/rural divide }\end{array}$ & $\begin{array}{l}\text { Not } \\
\text { supported }\end{array}$ \\
\hline The Hague & Positive coordination & $\begin{array}{l}\text { - Low vertical institutional fragmentation } \\
\text { - Low local tax autonomy } \\
\text { - Complementary economic bases }\end{array}$ & Supported \\
\hline $\begin{array}{l}\text { Washington, } \\
\text { D.C. }\end{array}$ & $\begin{array}{l}\text { Beggar-my-neighbor } \\
\text { behavior }\end{array}$ & $\begin{array}{l}\text { - High vertical institutional fragmentation } \\
- \text { High local tax autonomy }\end{array}$ & Supported
\end{tabular}

Additional explanatory factors are italicized.

With regard to institutional fragmentation, the case studies revealed that second-tier borders, i.e. state, province or canton borders, are powerful institutional constraints to the coordination of locational policies. The cases of Washington, D.C. and Ottawa-Gatineau show how intermunicipal coordination fails due to the second-tier borders that divide the SCC region into two or more separate political entities. However, as illustrated by the case of Bern, the integration of the whole metropolitan region into one single second-tier political entity is not a guarantee for the successful coordination of locational policies. Furthermore, the interviewees in Bern and Washington, D.C. do not consider horizontal institutional fragmentation, i.e. high numbers of local governments, as a decisive factor that hinders the coordination of locational policies. In sum, vertical institutional fragmentation is a powerful constraint to the coordination of locational policies, but it alone does not explain the successful coordination of locational policies. 
Regarding local tax autonomy, it seems that the underlying rationale of ensuring efficient and lean government entities via tax competition is at odds with the underlying rationale of coordination as a welfare theoretical concept (Scharpf 1994). More specifically, our cases point to an interaction effect between the two institutional factors: High local tax autonomy is an obstacle to the coordination of locational policies, but it only unfolds its full negative effect in vertically fragmented metropolitan regions. The combination of both institutional factors creates an unlevel playing field for local tax competition. The case of Washington, D.C. shows that jurisdictions with lower tax autonomy, i.e. fewer tax instruments at hand, compete more fiercely to survive in this unlevel tax competition. In Washington, D.C., this interaction effect has led to beggar-my-neighbor behavior, which can be considered as full coordination failure. Tax competition in Bern is comparably moderate, as it is played on a level playing field. The local jurisdictions in the Ottawa-Gatineau metropolitan region have different tax settings because of vertical institutional fragmentation, but the limited local tax autonomy prevents a fierce (tax) competition. This finding supports Leitner's and Sheppard's argument: "When cities in competition face unequal conditions of possibility [i.e. an unlevel playing field] these not only affect the nature of local initiatives but also work to undermine the putative general benefits of entrepreneurial strategies: (...), and creating zero-sum or negative-sum game of 'beggar thy neighbor"' (1999, 242).

These findings can be better understood when we distinguish between coordination as a process and policy coherence as the intended outcome of coordination (Cejudo and Michel 2017; Nordbeck and Steurer 2015). Whereas low vertical institutional fragmentation enables coordination as a process, locational policy coherence only occurs in contexts of low local tax autonomy. As the cases of Ottawa-Gatineau and Washington, D.C. demonstrate, vertical institutional fragmentation hinders the initiation of coordination because the jurisdictions belong to different lines of authority. As the case of Bern shows, high local tax autonomy is not necessarily an obstacle for coordination but if the involved jurisdictions feature high local tax 
autonomy the coordination process does not result in locational policy coherence as too much tax revenue is at stake. Thus, institutional fragmentation can be conceived of as the upstream explanatory factor because it is decisive for whether locational policy coordination is initiated or not, whereas local tax autonomy can be seen as the downstream explanatory factor decisive for whether policy coherence is successfully achieved or not. Low tax autonomy thus serves as the main consolidating factor fostering policy coherence.

While our study found an interaction effect between the two hard institutional factors, the cases also reveal the importance of politics. In its essence, coordination is an about agency, interests and power relations. In Bern, local decision-makers fear losing the autonomy of their municipality. The partisan divide that exists between the core city and the municipalities in the agglomeration enhances this fear. In Ottawa-Gatineau, Quebec's separatist movement is an important barrier to coordination. In the case of The Hague, the new coordination structure of Rotterdam and The Hague can be viewed through the lens of a political power play between the province and its two biggest cities. And in Washington, D.C., the different political settings of the three states, as well as the very special constitutional status of the District of Columbia and nation state interests, all aggravate regional coordination. Hence, politics matters: "Cooperation results from bargaining and negotiating among the officials of affected jurisdictions" (Dowding and Feiock 2012, 37). The cases provide a strong argument against any kind of institutionalist determinism and highlights the importance of incorporating structural and agency-based explanations (Ward, Imbroscio, Martin, Stone, Whelan, Miraftab, and Cochrane 2011). Institutions do not directly enable or constrain political processes; politics is an explanatory factor in its own right and proves to be an important driver or barrier to coordination.

Finally, the subjects of this study are cities that have very specific functions. Their role as capital cities was identified in the begging of this article as a reason why jurisdictions in SCC regions 
may decide to coordinate their locational policies. However, the capital city function cannot serve as a metropolitan-wide integration concept. In Washington, D.C., the regional economy heavily depends on the capital city function. For example, locational policies formulated in the District of Columbia and Arlington are similar but the unlevel playing field appears to trump any possible synergy effects for coordinating locational policies. Neither the capital city function, nor the common threat of federal government downsizing, has led to a coordinated locational policies agenda. In contrast, The Hague and Rotterdam feature two complementary economic bases, which, according to some interview partners, enable the establishment of coordination structures at the metropolitan level.

\section{Conclusion}

The motivation for this study was to identify the specific need for coordinating locational policies in secondary capital cities (SCCs), defined as capitals that are not the prime economic city of their nation states. SCCs serve as the political center of their nations, but they have to simultaneously find ways to develop their regional economies. Locational policies, and their regional coordination, are the prime policy instruments used to strengthen the economic competitiveness of a metropolitan region. We derived a pragmatic institutionalist framework with two explanatory factors for coordination and we expected that high institutional fragmentation in a metropolitan region and high local tax autonomy would aggravate the coordination of locational policies in a SCC metropolitan region.

The institutional framework that we derived from theory seems to be a simple but powerful research heuristic for analyzing coordination in metropolitan regions in general. Notwithstanding, the integration of political factors could have been better anticipated and integrated into the theoretical framework. This would have allowed us to account for the simultaneity of structure and agency (Ward et al. 2011). 
Our comparative study of the four capital city regions of Bern, Ottawa-Gatineau, The Hague and Washington, D.C. suggests that the combination of vertical institutional fragmentation and local tax autonomy explains the success or failure of coordinating locational policies. Local tax autonomy has the largest negative effect on coordination in vertically institutional fragmented metropolitan regions because this combination creates an unlevel playing field for tax competition. However, there is no institutional determinism at work. Coordination is a matter of politics just as much as it is formed by institutional context.

These findings are a piece of bad news for SCCs in general, because they tend to be located in metropolitan regions with vertical institutional fragmentation and the capital city-specific local tax autonomy constraints makes the regional tax playing field unlevel. Furthermore, the capital city function has not been found to serve as a metropolitan-wide locational policy integration concept. Therefore, we are proposing a couple of recommendations for pursuing the coordination of locational policies in SCCs. First, the findings indicate that second-tier political entities, such as member states or provinces, can emulate institutional consolidation, which supports inter-municipal coordination. Second, coordination comes with a political price tag. In order to foster coordination, it is necessary for there to be a common understanding of the SCC region that is accepted among all coordinating actors. Promoters of coordination may want to invest in a common problem understanding that goes beyond the capital city function. Third, SCCs have an ace up their sleeve and may not realize it. The capital city function is a good argument for treating SCCs well. If the central government is reminded of the importance of having a well-functioning capital, it may direct resources to coordinating bodies within SCCs instead of only to provinces or cities. 


\section{References}

Andeweg, Rudy, and Galen Irwin. 2014. Governance and Politics of the Netherlands. Palgrave Macmillan.

Andrew, Caroline, and David Doloreux. 2014. Linking Innovation and Inclusion: The Governance Question in Ottawa. In Governing Urban Economies: Innovation and Inclusion in Canadian City-Regions, edited by Neil Bradford and Allison Bramwell: 137-60. University of Toronto Press.

Burger, Martijn J, Evert J Meijers, Marloes M Hoogerbrugge, and Jaume Masip Tresserra. 2015. Borrowed Size, Agglomeration Shadows and Cultural Amenities in North-West Europe. European Planning Studies 23 (6): 1090-1109.

Campbell, Scott. 2000. The Changing Role and Identity of Capital Cities in the Global Era.” Paper Presented at the Annual Meeting of American Geographers. Pittsburgh, PA.

Cejudo, Guillermo, and Cynthia Michel. 2017. Addressing fragmented government action: coordination, coherence, and integration. Policy Sciences. Early Online.

Cohen, Natalie. 2000. Business Location Decision-Making and the Cities: Bringing Companies Back. Brookings Institution Center on Urban and Metropolitan Policy.

Collier, David, and Henry E Brady. 2010. Rethinking Social Inquiry: Diverse Tools, Shared Standards. Rowman \& Littlefield Publishers.

Dowding, Keith, and Richard Feiock. 2012. Intralocal competition and cooperation. In: The Oxford Handbook of Urban Politics edited by Karen Mossberger, Susane Clarke, and Peter John: 29-50. Oxford: Oxford University Press.

Feiock, Richard C. 2013. The institutional collective action framework. Policy Studies Journal 41 (3): 397-425. 
Feiock, Richard. C., Anette Steinacker, Hyung Jun Park. 2009. Institutional Collective Action and Economic Development Joint Ventures. Public Administration Review 69: 256270

Federal Finance Administration. 2016. Einnahmen-2014: Städte und Kantonshauptorte. Available online at https://www.efv.admin.ch/efv/de/home/themen/finanzstatistik/berichterstattung.html [accessed date: 16 May 2017]

Ghandi, Natwar, Yesim Yilmaz, Robert Zahradnik, and Marcy Edwards. 2009. Washington, District of Columbia, United States of America. In Finance and Governance of Capital Cities in Federal Systems, edited by Enid Slack and Rupak Chattopadhyay, 263-91. McGill-Queen's University Press.

Goldsmith, Michael. 2012. "Cities in Intergovernmental Systems.” In The Oxford Handbook of Urban Politics, edited by Karen Mossberger, Susan E Clarke, and Peter John, 133151. Oxford University Press.

Hamilton, Alexander, James Madison, and John Jay. 1982. The Federalist Papers. New York: Bantam.

Hall, Peter G.. 2006. Seven Types of Capital City. In Planning Twentieth Century Capital Cities, edited by David L. A Gordon, 8-14. New York: Routledge.

Hall, Peter G. and Kathy Pain (eds). 2001. The Polycentric Metropolis. Learning from MegaCity Regions in Europe. London: Earthscan.

Harris, Charles Wesley. 1995. Congress and the Governance of the Nation's Capital: The Conflict of Federal and Local Interests. Georgetown University Press.

Hoffmann-Martinot, Vincent and Jefferey Sellers (eds). 2005. Metropolitanization and political change. Springer. 
Kaufmann, David. 2018. Varieties of Capital Cities: The Competitiveness Challenge for Secondary Capitals. Cheltenham: Edward Elgar.

Kaufmann, David, and Tobias Arnold. 2018. Strategies of cities in globalized interurban competition: the locational policies framework, Urban Studies. Early Online.

Kaufmann, David, Martin Warland, Heike Mayer, and Fritz Sager. 2016. Bern’s positioning strategies: Escaping the fate of a secondary capital city?, Cities 53: 120-129.

Keating, Michael. 1995. Size, Efficency and Democracy: Consolidation, Fragmentation and Public Choice. In Theories of Urban Politics, edited by David Judge, Gerry Stoker, and Harold Wolman: 117-34. SAGE Publications Limited.

Koch, Philippe. 2013. Overestimating the shift from government to governance: Evidence from Swiss metropolitan areas. Governance 26 (3): 397-423.

Kübler, Daniel, and Jolita Piliutyte. 2007. Intergovernmental Relations and International Urban Strategies: Constraints and Opportunities in Multilevel Polities. Environment and Planning C: Government and Policy 25 (3): 357-73.

Leitner, Helga, and Eric Sheppard. 1999. Transcending interurban competition: Conceptual issues and policy alternatives in the European Union. In: The growth machine: Critical perspectives twenty years later, edited by Andrew E.G. Jonas, and David Wilson: 227246. Albany: State University of New York Press.

Lijphart, Arend. 1975. "II. the Comparable-Cases Strategy in Comparative Research." Comparative Political Studies 8 (2): 158-77.

Mayer, Heike, Fritz Sager, David Kaufmann, and Martin Warland. 2018. The Political Economy of Capital Cities. London: Routledge.

Mayer, Heike, Fritz Sager, David Kaufmann, and Martin Warland. 2016. Capital city dynamics: Linking regional innovation systems, locational policies and policy regimes, Cities 51: 11-20. 
Meijers, Evert, Marloes Hoogerbrugge, Erik Louw, Hugo Priemus, and Marjolein Spaans. 2014. City Profile: The Hague. Cities 41: 92-100.

Morgan, Kevin. 2014. The Rise of Metropolis: Urban Governace in the Age of the CityRegion. In Governing Urban Economies: Innovation and Inclusion in Canadian CityRegions, edited by Neil Bradford and Allison Bramwell: 297-318. University of Toronto Press.

Moser, Sarah. 2010. Putrajaya: Malaysia's New Federal Administrative Capital. Cities 27 (4): $285-297$.

Nordbeck, Ralf, and Reinhard Steurer. 2016. Multi-sectoral strategies as dead ends of policy integration: Lessons to be learned from sustainable development. Environment and Planning C: Government and Policy 34 (4): 737-755.

OECD. 2014. OECD Fiscal Decentralization Database. Available online at https://www.oecd.org/tax/fiscal-decentralisation-database.htm\#A_Title [accessed data: 16 May 20017]

Ostrom, Elinor. 1990. Governing the Commons: The Evolution of Institutions for Collective Action. Cambridge University Press.

Page, Edward, and Michael Goldsmith. 1987. Central and Local Government Relations: A Comparative Analysis of West European Unitary States. London: Sage Publications.

Pierre, Jon. 2005. Comparative Urban Governance Uncovering Complex Causalities. Urban Affairs Review 40 (4): 446-462.

Przeworski, Adam and Henry Teune. 1970. The Logic of Comparative Social Inquiry. New York: John Wiley.

Rowat, Donald Cameron. 1973. The government of federal capitals. Toronto: University of Toronto Press. 
Sager, Fritz. 2005. Metropolitan Institutions and Policy Coordination: The Integration of Land Use and Transport Policies in Swiss Urban Areas. Governance 18 (2): 227-256.

Sager, Fritz. 2006. Policy Coordination in the European Metropolis: A Meta-Analysis. West European Politics 29 (3): 433-460.

Scharpf, Fritz. 1994. Games Real Actors Could Play: Positive and Negative Coordination in Embedded Negotiations. Journal of Theoretical Politics 6 (1): 27-53.

Scharpf, Fritz. 1997. Games Real Actors Play: Actor-Centered Institutionalism in Policy Research. Westview Press Boulder.

Sellers, Jefferey and Anders Lidström. 2007. Decentralization, local government, and the welfare state. Governance 20 (4): 609-632.

Slack, Enid, and Rupak Chattopadhyay. 2009. Finance and Governance of Capital Cities in Federal Systems. McGill-Queen's University Press.

Van der Heiden, Nico. 2010. Urban Foreign Policy and Domestic Dilemmas: Insights from Swiss and EU City-Regions. Colchester: ECPR.

Van Krieken, Peter, and David McKay. 2005. The Hague: Legal Capital of the World. The Hague: T-M-C Asser Press.

Ward, Kevin, David Imbroscio, Deborah Martin, Clarence Stone, Robert Whelan, Faranak Miraftab, and Allan Cochrane. 2011. "Urban Politics: An Interdisciplinary Dialogue.” International Journal of Urban and Regional Research 35 (4): 853-871. 


\section{Appendix}

TABLE A1

\section{List of interview partners}

\begin{tabular}{|c|c|c|c|c|}
\hline $\begin{array}{l}\text { Interview } \\
\text { number }\end{array}$ & City & Name & Role & Relevant affiliation(s) \\
\hline 1 & Bern & Bratschi, Peter & $\begin{array}{l}\text { Private actor/Interest group } \\
\text { representative }\end{array}$ & $\begin{array}{l}\text { Partner and lawyer, Bratschi Wiederkehr \& Buob } \\
\text { Founder, Circle of Bern (Berner Runde) }\end{array}$ \\
\hline 2 & Bern & Bucher, Jürg & $\begin{array}{l}\text { Private actor/Interest group } \\
\text { representative }\end{array}$ & $\begin{array}{l}\text { Chairman of the Board of Directors, Valiant } \\
\text { Bank AG (Swiss bank) } \\
\text { Ex-Chief Executive Officer, Swiss Post }\end{array}$ \\
\hline 3 & Bern & Buchmüller, Regula & Public official & Senior public servant, City of Bern \\
\hline 4 & Bern & Fluri, Kurt & Public official & $\begin{array}{l}\text { Member, Swiss Parliament } \\
\text { Mayor, City of Solothurn } \\
\text { President, Association of Swiss Cities (Schweizer } \\
\text { Städteverband) } \\
\text { Board member, Capital Region Switzerland }\end{array}$ \\
\hline 5 & Bern & Gasche, Urs & $\begin{array}{l}\text { Private actor/Interest group } \\
\text { representative }\end{array}$ & $\begin{array}{l}\text { Chairman of the Board of Directors, BKW } \\
\text { group } \\
\text { Member, Swiss Parliament } \\
\text { Member, Circle of Bern (Berner Runde) }\end{array}$ \\
\hline 6 & Bern & Gehrig, Orlando & $\begin{array}{l}\text { Economic development } \\
\text { agent }\end{array}$ & $\begin{array}{l}\text { Vice-President of Strategic Location } \\
\text { Development, Bern Economic Development } \\
\text { Agency (Canton of Bern) }\end{array}$ \\
\hline 7 & Bern & Jocham, Uwe & $\begin{array}{l}\text { Private actor/Interest group } \\
\text { representative }\end{array}$ & $\begin{array}{l}\text { Senior Vice President and General Manager, } \\
\text { CSL Behring AG } \\
\text { President, Employer Association Canton of Bern } \\
\text { Member, Board of the Chamber of Commerce } \\
\text { of the Canton of Bern } \\
\text { Member, Circle of Bern (Berner Runde) } \\
\text { Member, Fokus Bern }\end{array}$ \\
\hline 8 & Bern & Messerli, Paul & Expert & $\begin{array}{l}\text { Professor Emeritus, University of Bern, } \\
\text { Economic Geographer }\end{array}$ \\
\hline 9 & Bern & Müller, Hans-Ulrich & $\begin{array}{l}\text { Private actor/Interest group } \\
\text { representative }\end{array}$ & $\begin{array}{l}\text { President, Swiss Venture Club } \\
\text { Head of Swiss Partnerships, Credit Suisse }\end{array}$ \\
\hline 10 & Bern & Nietlisbach, André & Public official & $\begin{array}{l}\text { Senior public servant, Economic Department of } \\
\text { the Canton of Bern }\end{array}$ \\
\hline 11 & Bern & Pfyl, Thomas & Public official & Financial Manager, Municipality of Köniz, \\
\hline \multirow{2}{*}{12} & Bern & Poschet, Lena & Public official & $\begin{array}{l}\text { Head of department, Federal Office for Spatial } \\
\text { Development }\end{array}$ \\
\hline & Bern & Gilgen Thetaz, Regina & Public official & $\begin{array}{l}\text { Research associate, Federal Office for Spatial } \\
\text { Development) }\end{array}$ \\
\hline 13 & Bern & Rytz, Regula & $\begin{array}{l}\text { Private actor/Interest group } \\
\text { representative }\end{array}$ & $\begin{array}{l}\text { Member, Swiss Parliament } \\
\text { Co-President, Green Party of Switzerland } \\
\text { Ex-member, City Council of Bern } \\
\text { Co-President, Bern Neu Gründen }\end{array}$ \\
\hline 14 & Bern & Stampfli, Katharina & $\begin{array}{l}\text { Economic development } \\
\text { agent }\end{array}$ & $\begin{array}{l}\text { Member, Executive Board of the Economic } \\
\text { Area of Bern (Bern Wirtschaftsraum) }\end{array}$ \\
\hline 15 & Bern & Stämpfli, Peter & $\begin{array}{l}\text { Private actor/Interest group } \\
\text { representative }\end{array}$ & $\begin{array}{l}\text { Chairman of the Board of Directors, Stämpfli } \\
\text { AG } \\
\text { Founder, Fokus Bern } \\
\text { Member, Circle of Bern (Berner Runde) }\end{array}$ \\
\hline 16 & Bern & Steiner, Jürg & Expert & $\begin{array}{l}\text { Journalist, Berner Zeitung } \\
\text { Author }\end{array}$ \\
\hline 17 & Bern & Tobler, Georg & $\begin{array}{l}\text { Economic development } \\
\text { agent }\end{array}$ & Managing Director, Capital Region Switzerland \\
\hline 18 & Bern & Tschäppat, Alexander & Public official & $\begin{array}{l}\text { Mayor, City of Bern } \\
\text { Member, Swiss Parliament } \\
\text { Board member, Capital Region Switzerland }\end{array}$ \\
\hline 19 & Bern & Walter, Felix & Expert & Head of the Economic Department, Ecoplan \\
\hline 20 & The Hague & Adarghal, Karim & Public official & $\begin{array}{l}\text { Account Manager of the IT/Telecom industry, } \\
\text { City of The Hague }\end{array}$ \\
\hline 21 & The Hague & Blokmaker, Daniel & $\begin{array}{l}\text { Private actor/Interest group } \\
\text { representative }\end{array}$ & $\begin{array}{l}\text { Entrepreneur } \\
\text { Ex-Business Development \& Innovation } \\
\text { Manager, KPN Telecom }\end{array}$ \\
\hline 22 & The Hague & de Vries, Jouke & Expert & $\begin{array}{l}\text { Professor of Public Administration, Leiden } \\
\text { University } \\
\text { Dean of The Hague Campus, Leiden University }\end{array}$ \\
\hline 23 & The Hague & den Bruinen, Joris & $\begin{array}{l}\text { Economic development } \\
\text { agent }\end{array}$ & Deputy Director, The Hague Security Delta \\
\hline 24 & The Hague & Dencher, Robert & $\begin{array}{l}\text { Private actor/Interest group } \\
\text { representative }\end{array}$ & $\begin{array}{l}\text { Head of Government Relations Netherlands, } \\
\text { Shell International }\end{array}$ \\
\hline 25 & The Hague & Genet, Louis & Public official & $\begin{array}{l}\text { Director Investments International City The } \\
\text { Hague, City of The Hague, }\end{array}$ \\
\hline
\end{tabular}




\begin{tabular}{|c|c|c|c|c|}
\hline & The Hague & van der Klaauw, Marcel & Public official & Senior Policy Advisor, City of The Hague \\
\hline 26 & The Hague & Groen, Rosa & Expert & $\begin{array}{l}\text { Lecturer, The Hague University of Applied } \\
\text { Sciences }\end{array}$ \\
\hline 27 & The Hague & $\begin{array}{l}\text { Hillen, Vincent } \\
\text { written interview }\end{array}$ & Public official & $\begin{array}{l}\text { Senior Financial Policy Officer, City of The } \\
\text { Hague }\end{array}$ \\
\hline \multirow[b]{2}{*}{28} & The Hague & Houtzagers, Bert-Jan & $\begin{array}{l}\text { Private actor/Interest group } \\
\text { representative }\end{array}$ & $\begin{array}{l}\text { Dutch State Advocate } \\
\text { Partner and lawyer, Pels Rijcken \& Droogleever } \\
\text { Fortuijn }\end{array}$ \\
\hline & The Hague & Scheltema, Martijn & $\begin{array}{l}\text { Private actor/Interest group } \\
\text { representative }\end{array}$ & $\begin{array}{l}\text { Partner and lawyer, Pels Rijcken \& Droogleever } \\
\text { Fortuijn } \\
\text { Professor, Erasmus University Rotterdam }\end{array}$ \\
\hline 29 & The Hague & Janssen, Sander & Public official & $\begin{array}{l}\text { Head of the Host Nation Division, Dutch } \\
\text { Ministry of Foreign Affairs }\end{array}$ \\
\hline 30 & The Hague & Kok, Laurens & $\begin{array}{l}\text { Economic development } \\
\text { agent }\end{array}$ & $\begin{array}{l}\text { Foreign Investor Relations Manager, West- } \\
\text { Holland Foreign Investment Agency }\end{array}$ \\
\hline 31 & The Hague & Krohl, Niels & $\begin{array}{l}\text { Economic development } \\
\text { agent }\end{array}$ & $\begin{array}{l}\text { Senior Investor Relations Manager, } \\
\text { InnovationQuarter }\end{array}$ \\
\hline 32 & The Hague & Meijers, Evert & Expert & $\begin{array}{l}\text { Professor, Delft University of Technology, } \\
\text { Economic Geographer }\end{array}$ \\
\hline 33 & The Hague & Oliver, Iris & Public official & $\begin{array}{l}\text { Senior Strategic Account Manager, City of The } \\
\text { Hague }\end{array}$ \\
\hline 34 & The Hague & Schiebroek, Marleen & Expert & Consultant, Brain \& Company \\
\hline 35 & The Hague & Schuttenbeld, Ben & $\begin{array}{l}\text { Private actor/Interest group } \\
\text { representative }\end{array}$ & $\begin{array}{l}\text { Senior Advisor, Chamber of Commerce of } \\
\text { Southwest Holland }\end{array}$ \\
\hline 36 & The Hague & Shimshon, Gideon & Expert & $\begin{array}{l}\text { Director, Centre for Innovation Leiden } \\
\text { University }\end{array}$ \\
\hline 37 & The Hague & van der Linden, Harry & Public official & $\begin{array}{l}\text { Advisor, Dutch Ministry of Economic Affairs, } \\
\text { Regional Affairs and Spatial Policy }\end{array}$ \\
\hline 38 & The Hague & van Geelen, Nicolas & Public official & $\begin{array}{l}\text { Strategic Advisor on Administration \& Policy, } \\
\text { Province South Holland }\end{array}$ \\
\hline 39 & The Hague & van Haelst, Nicole & $\begin{array}{l}\text { Private actor/Interest group } \\
\text { representative }\end{array}$ & Director, International Community Platform \\
\hline 40 & The Hague & van Loon, Branko & Public official & $\begin{array}{l}\text { Policy Advisor on International Affairs, City of } \\
\text { The Hague }\end{array}$ \\
\hline \multirow{2}{*}{41} & The Hague & van Ommeren, Kees & Expert & Partner and Founder, Decisio \\
\hline & The Hague & Wijnen, Mathieu & Expert & Junior Advisor, Decisio \\
\hline \multirow{2}{*}{42} & The Hague & van Vondel, Esther & Public official & $\begin{array}{l}\text { Senior Policy Officer for International } \\
\text { Economic Affairs, City of The Hague }\end{array}$ \\
\hline & The Hague & de Vries, Matthijs & Public official & $\begin{array}{l}\text { Senior Advisor on Spatial Economic Strategy \& } \\
\text { Policy, City of The Hague }\end{array}$ \\
\hline \multirow[b]{2}{*}{43} & The Hague & Vokurka, Lucas & $\begin{array}{l}\text { Economic development } \\
\text { agent }\end{array}$ & $\begin{array}{l}\text { Director of Economic Development, } \\
\text { Metropolitan Region Rotterdam The Hague }\end{array}$ \\
\hline & The Hague & Nijhof, Bart & $\begin{array}{l}\text { Economic development } \\
\text { agent }\end{array}$ & $\begin{array}{l}\text { Process Manager of Economic Development, } \\
\text { Metropolitan Region Rotterdam The Hague } \\
\text { Ex-regional Economic Cooperation Policy } \\
\text { Advisor City of Rotterdam }\end{array}$ \\
\hline 44 & $\begin{array}{l}\text { Ottawa- } \\
\text { Gatineau }\end{array}$ & Bashir, Saad & Public official & $\begin{array}{l}\text { Director of Economic Development \& } \\
\text { Innovation, City of Ottawa }\end{array}$ \\
\hline 45 & $\begin{array}{l}\text { Ottawa- } \\
\text { Gatineau }\end{array}$ & Bird, Graham & $\begin{array}{l}\text { Private actor/Interest group } \\
\text { representative }\end{array}$ & $\begin{array}{l}\text { President, GBA Development \& Project } \\
\text { Management, Developer }\end{array}$ \\
\hline 46 & $\begin{array}{l}\text { Ottawa- } \\
\text { Gatineau }\end{array}$ & Champagne, Eric & Expert & $\begin{array}{l}\text { Associate Professor in Public Administration, } \\
\text { University of Ottawa }\end{array}$ \\
\hline 47 & $\begin{array}{l}\text { Ottawa- } \\
\text { Gatineau }\end{array}$ & Chattopadhyay, Rupak & Expert & President and CEO, Forum of Federations \\
\hline 48 & $\begin{array}{l}\text { Ottawa- } \\
\text { Gatineau }\end{array}$ & Light, John & Expert & $\begin{array}{l}\text { Ex-Director of Regional Affairs for the Minister } \\
\text { of Foreign Affairs John Baird }\end{array}$ \\
\hline 49 & $\begin{array}{l}\text { Ottawa- } \\
\text { Gatineau }\end{array}$ & Dale, Jeffery & $\begin{array}{l}\text { Economic development } \\
\text { agent }\end{array}$ & $\begin{array}{l}\text { Ex-President, Ottawa Centre for Research and } \\
\text { Innovation }\end{array}$ \\
\hline 50 & $\begin{array}{l}\text { Ottawa- } \\
\text { Gatineau }\end{array}$ & Faris, Ian & $\begin{array}{l}\text { Private actor/Interest group } \\
\text { representative }\end{array}$ & $\begin{array}{l}\text { President \& Chief Executive Officer, Ottawa } \\
\text { Chamber of Commerce }\end{array}$ \\
\hline 51 & $\begin{array}{l}\text { Ottawa- } \\
\text { Gatineau }\end{array}$ & Fielding, John & $\begin{array}{l}\text { Economic development } \\
\text { agent }\end{array}$ & $\begin{array}{l}\text { Regional Director of Business Development } \\
\text { Eastern \& Northern Ontario, Ontario Centres } \\
\text { of Excellence }\end{array}$ \\
\hline 52 & $\begin{array}{l}\text { Ottawa- } \\
\text { Gatineau }\end{array}$ & Kristmanson, Mark & Public official & $\begin{array}{l}\text { Chief Executive Officer, National Capital } \\
\text { Commission }\end{array}$ \\
\hline 53 & $\begin{array}{l}\text { Ottawa- } \\
\text { Gatineau }\end{array}$ & La Flamme, Guy & Public official & Executive Director, Ottawa 2017 Bureau \\
\hline 54 & $\begin{array}{l}\text { Ottawa- } \\
\text { Gatineau }\end{array}$ & La Pointe, Francois & Public official & $\begin{array}{l}\text { Ex-Senior Executive of Capital Planning, } \\
\text { National Capital Commission } \\
\text { Senior Fellow, Centre on Governance, } \\
\text { University of Ottawa }\end{array}$ \\
\hline 55 & $\begin{array}{l}\text { Ottawa- } \\
\text { Gatineau }\end{array}$ & Lazenby, Bruce & $\begin{array}{l}\text { Economic development } \\
\text { agent }\end{array}$ & $\begin{array}{l}\text { President and Chief Executive Officer, Invest } \\
\text { Ottawa }\end{array}$ \\
\hline 56 & $\begin{array}{l}\text { Ottawa- } \\
\text { Gatineau }\end{array}$ & McNabb, David & Public official & $\begin{array}{l}\text { Acting Director General of Strategic Policy, } \\
\text { FedDev Ontario }\end{array}$ \\
\hline 57 & $\begin{array}{l}\text { Ottawa- } \\
\text { Gatineau }\end{array}$ & Normand, Antoine & $\begin{array}{l}\text { Private actor/Interest group } \\
\text { representative }\end{array}$ & President, Gatineau Chamber of Commerce \\
\hline
\end{tabular}




\begin{tabular}{|c|c|c|c|c|}
\hline 58 & $\begin{array}{l}\text { Ottawa- } \\
\text { Gatineau }\end{array}$ & Paquet, Gilles & Expert & $\begin{array}{l}\text { Professor Emeritus, Telfer School of } \\
\text { Management, University of Ottawa }\end{array}$ \\
\hline 59 & $\begin{array}{l}\text { Ottawa- } \\
\text { Gatineau }\end{array}$ & Ritonja, David & $\begin{array}{l}\text { Private actor/Interest group } \\
\text { representative }\end{array}$ & $\begin{array}{l}\text { Vice President, Alcatel-Lucent } \\
\text { Co-Chair, Invest Ottawa }\end{array}$ \\
\hline 60 & $\begin{array}{l}\text { Ottawa- } \\
\text { Gatineau }\end{array}$ & Saric, Sandra & $\begin{array}{l}\text { Economic development } \\
\text { agent }\end{array}$ & $\begin{array}{l}\text { Vice President of Talent Innovation, } \\
\text { Information and Communications Technology } \\
\text { Council }\end{array}$ \\
\hline 61 & $\begin{array}{l}\text { Ottawa- } \\
\text { Gatineau }\end{array}$ & Sudds, Jenna & $\begin{array}{l}\text { Private actor/Interest group } \\
\text { representative }\end{array}$ & $\begin{array}{l}\text { Executive Director, Kanata North Business } \\
\text { Association }\end{array}$ \\
\hline \multirow{2}{*}{62} & $\begin{array}{l}\text { Ottawa- } \\
\text { Gatineau }\end{array}$ & Temsamani, Jalia & $\begin{array}{l}\text { Economic development } \\
\text { agent }\end{array}$ & $\begin{array}{l}\text { Business development advisor, Développement } \\
\text { économique - CLD Gatineau }\end{array}$ \\
\hline & $\begin{array}{l}\text { Ottawa- } \\
\text { Gatineau }\end{array}$ & Cameron-Nunes, Émilie & $\begin{array}{l}\text { Economic development } \\
\text { agent }\end{array}$ & $\begin{array}{l}\text { Responsable de la diversité culturelle, Ville de } \\
\text { Gatineau }\end{array}$ \\
\hline 63 & $\begin{array}{l}\text { Ottawa- } \\
\text { Gatineau }\end{array}$ & Terry, Bernadette & $\begin{array}{l}\text { Economic development } \\
\text { agent }\end{array}$ & $\begin{array}{l}\text { Senior Business Development Lead for the } \\
\text { Aerospace, Defence \& Security Sector, Invest } \\
\text { Ottawa }\end{array}$ \\
\hline 64 & $\begin{array}{l}\text { Ottawa- } \\
\text { Gatineau }\end{array}$ & Varriano, Franco & $\begin{array}{l}\text { Private actor/Interest group } \\
\text { representative }\end{array}$ & $\begin{array}{l}\text { Director, Startup Grind Ottawa } \\
\text { Entrepreneur }\end{array}$ \\
\hline 65 & $\begin{array}{l}\text { Washington } \\
\text { D.C. }\end{array}$ & Barros, Francis & Public official & $\begin{array}{l}\text { Program Manager Small Business Services, } \\
\text { Department of Homeland Security }\end{array}$ \\
\hline 66 & $\begin{array}{l}\text { Washington } \\
\text { D.C. }\end{array}$ & Bean, Chuck & $\begin{array}{l}\text { Economic development } \\
\text { agent }\end{array}$ & $\begin{array}{l}\text { Executive Director, Metropolitan Washington } \\
\text { Council of Governments }\end{array}$ \\
\hline 67 & $\begin{array}{l}\text { Washington } \\
\text { D.C. }\end{array}$ & Boyer, Laurie & $\begin{array}{l}\text { Economic development } \\
\text { agent }\end{array}$ & $\begin{array}{l}\text { Executive Director, Rockville Economic } \\
\text { Development } \\
\text { Co-President, Council of Economic } \\
\text { Development Officials }\end{array}$ \\
\hline 68 & $\begin{array}{l}\text { Washington } \\
\text { D.C. }\end{array}$ & Buchanan, Robert E. & $\begin{array}{l}\text { Private actor/Interest group } \\
\text { representative }\end{array}$ & $\begin{array}{l}\text { Partner, Buchanan Partners, Developer } \\
\text { Member, } 2030 \text { Business group }\end{array}$ \\
\hline 69 & $\begin{array}{l}\text { Washington } \\
\text { D.C. }\end{array}$ & Clinton, Kevin & $\begin{array}{l}\text { Private actor/Interest group } \\
\text { representative }\end{array}$ & Chief Operating Officer, Federal City Council \\
\hline 70 & $\begin{array}{l}\text { Washington } \\
\text { D.C. }\end{array}$ & D'Amore, Kristin & $\begin{array}{l}\text { Private actor/Interest group } \\
\text { representative }\end{array}$ & $\begin{array}{l}\text { Director of Strategic Initiatives and President of } \\
\text { The Entrepreneur Center, Northern Virginia } \\
\text { Technology Council }\end{array}$ \\
\hline 71 & $\begin{array}{l}\text { Washington } \\
\text { D.C. }\end{array}$ & Fuller, Stephen & Expert & $\begin{array}{l}\text { Professor, George Mason University, Public } \\
\text { Policy and Regional Development, Center for } \\
\text { Regional Analysis }\end{array}$ \\
\hline \multirow{2}{*}{72} & $\begin{array}{l}\text { Washington } \\
\text { D.C. }\end{array}$ & Hawkins, Val & $\begin{array}{l}\text { Economic development } \\
\text { agent }\end{array}$ & $\begin{array}{l}\text { Ex-President \& Chief Executive Officer, } \\
\text { Alexandria Economic Development Partnership, } \\
\text { Inc. }\end{array}$ \\
\hline & $\begin{array}{l}\text { Washington } \\
\text { D.C. }\end{array}$ & Landrum, Stephanie & $\begin{array}{l}\text { Economic development } \\
\text { agent }\end{array}$ & $\begin{array}{l}\text { Current President \& Chief Executive Officer, } \\
\text { Alexandria Economic Development Partnership, } \\
\text { Inc. }\end{array}$ \\
\hline 73 & $\begin{array}{l}\text { Washington } \\
\text { D.C. }\end{array}$ & Khan, Sakina & Public official & $\begin{array}{l}\text { Senior Economic Planner, District of Columbia } \\
\text { Office of Planning }\end{array}$ \\
\hline \multirow{2}{*}{74} & $\begin{array}{l}\text { Washington } \\
\text { D.C. }\end{array}$ & Koster, Julia & Public official & $\begin{array}{l}\text { Director, Office of Public Engagement, National } \\
\text { Capital Planning Commission }\end{array}$ \\
\hline & $\begin{array}{l}\text { Washington } \\
\text { D.C. }\end{array}$ & Staudigl, Stephen & Public official & $\begin{array}{l}\text { Public Affairs Specialist, National Capital } \\
\text { Planning Commission }\end{array}$ \\
\hline 75 & $\begin{array}{l}\text { Washington } \\
\text { D.C. }\end{array}$ & Lazere, Ed & $\begin{array}{l}\text { Private actor/Interest group } \\
\text { representative }\end{array}$ & Executive Director, D.C. Fiscal Policy Institute \\
\hline 76 & $\begin{array}{l}\text { Washington } \\
\text { D.C. }\end{array}$ & Levine, Mark & $\begin{array}{l}\text { Private actor/Interest group } \\
\text { representative }\end{array}$ & $\begin{array}{l}\text { Managing Director, Core Capital Partners } \\
\text { Venture capitalist }\end{array}$ \\
\hline 77 & $\begin{array}{l}\text { Washington } \\
\text { D.C. }\end{array}$ & Loescher, Doug & Public official & $\begin{array}{l}\text { Ex- Director of Business Development and } \\
\text { Strategy, Washington D.C. Mayor's Office }\end{array}$ \\
\hline \multirow{2}{*}{78} & $\begin{array}{l}\text { Washington } \\
\text { D.C. }\end{array}$ & Richmond, Cynthia & $\begin{array}{l}\text { Economic development } \\
\text { agent }\end{array}$ & $\begin{array}{l}\text { Acting Director, Arlington Economic } \\
\text { Development }\end{array}$ \\
\hline & $\begin{array}{l}\text { Washington } \\
\text { D.C. }\end{array}$ & Winn, Christina & $\begin{array}{l}\text { Economic development } \\
\text { agent }\end{array}$ & $\begin{array}{l}\text { Director, Business Investment Group Arlington } \\
\text { Economic Development }\end{array}$ \\
\hline 79 & $\begin{array}{l}\text { Washington } \\
\text { D.C. }\end{array}$ & Rivlin, Alice & Expert & $\begin{array}{l}\text { Senior Fellow, Brookings Institutions } \\
\text { Visiting Professor, Georgetown University } \\
\text { Chair, District of Columbia Financial } \\
\text { Management Assistance Authority (1998-2001) }\end{array}$ \\
\hline 80 & $\begin{array}{l}\text { Washington } \\
\text { D.C. }\end{array}$ & $\begin{array}{l}\text { Ruble, Blair } \\
\text { written interview }\end{array}$ & Expert & $\begin{array}{l}\text { Director, Kennan Institute, Woodrow Wilson } \\
\text { International Center }\end{array}$ \\
\hline 81 & $\begin{array}{l}\text { Washington } \\
\text { D.C. }\end{array}$ & Smith, Walter & Expert & $\begin{array}{l}\text { Executive Director, DC Appleseed Center for } \\
\text { Law \& Justice }\end{array}$ \\
\hline 82 & $\begin{array}{l}\text { Washington } \\
\text { D.C. }\end{array}$ & Stone, Clarence & Expert & $\begin{array}{l}\text { Professor, George Washington University } \\
\text { Professor Emeritus, University of Maryland }\end{array}$ \\
\hline 83 & $\begin{array}{l}\text { Washington } \\
\text { D.C. }\end{array}$ & Stone, Nick & Expert & $\begin{array}{l}\text { Director of National Capital Region Operations, } \\
\text { Virginia Tech }\end{array}$ \\
\hline 84 & $\begin{array}{l}\text { Washington } \\
\text { D.C. }\end{array}$ & Tregoning, Harriet & Public official & $\begin{array}{l}\text { Principal Deputy Assistant Secretary, Office of } \\
\text { Community Planning and Development } \\
\text { Ex-Director, District of Columbia Office of } \\
\text { Planning }\end{array}$ \\
\hline 85 & $\begin{array}{l}\text { Washington } \\
\text { D.C. }\end{array}$ & Turner, Jeff & $\begin{array}{l}\text { Private actor/Interest group } \\
\text { representative }\end{array}$ & Managing Partner, Squire Patton Boggs \\
\hline
\end{tabular}




\begin{tabular}{|c|c|c|c|c|}
\hline 86 & $\begin{array}{l}\text { Washington } \\
\text { D.C. }\end{array}$ & Watkins, Matthew & $\begin{array}{l}\text { Private actor/Interest group } \\
\text { representative }\end{array}$ & $\begin{array}{l}\text { Economic Development Manager, Downtown } \\
\text { D.C. Business Improvement District }\end{array}$ \\
\hline 87 & $\begin{array}{l}\text { Washington } \\
\text { D.C. }\end{array}$ & White, Kyle & $\begin{array}{l}\text { Private actor/Interest group } \\
\text { representative }\end{array}$ & $\begin{array}{l}\text { Director, Economic Initiatives Greater } \\
\text { Washington Board of Trade }\end{array}$ \\
\hline \multirow{2}{*}{88} & $\begin{array}{l}\text { Washington } \\
\text { D.C. }\end{array}$ & Wolman, Hal & Expert & $\begin{array}{l}\text { Professor, George Washington University, } \\
\text { Political Scientist }\end{array}$ \\
\hline & $\begin{array}{l}\text { Washington } \\
\text { D.C. }\end{array}$ & Young, Gary & Expert & $\begin{array}{l}\text { Professor, George Washington University, } \\
\text { Political Scientist }\end{array}$ \\
\hline 89 & $\begin{array}{l}\text { Washington } \\
\text { D.C. }\end{array}$ & Zahradnik, Robert & Public official & $\begin{array}{l}\text { Ex-Director of Research, District of Columbia } \\
\text { Government, Office of Revenue Analysis } \\
\text { Director State Policy, The Pew Charitable Trusts }\end{array}$ \\
\hline 90 & $\begin{array}{l}\text { Washington } \\
\text { D.C. }\end{array}$ & Zipper, David & Public official & $\begin{array}{l}\text { Ex- Director of Business Development and } \\
\text { Strategy, Washington D.C. Mayor's Office } \\
\text { Managing Director, 1776, global start-up hub }\end{array}$ \\
\hline 91 & $\begin{array}{l}\text { Washington, } \\
\text { D.C. }\end{array}$ & Anonymous interview & Public official & Congressional staffer \\
\hline
\end{tabular}




\section{Definitions of metropolitan regions}

The data on population in Table 2 refers to the following definition of metropolitan regions and sources of population data:

The metropolitan region of Bern refers to the MS region 11 defined by the Swiss Federal Statistical Office. This region includes the following 29 municipalities: Allmendingen, Bäriswil, Belp, Bern, Bolligen, Bremgarten bei Bern, Deisswil bei Münchenbuchsee, Diemerswil, Frauenkappelen, Iffwil, Ittigen, Jegenstorf, Kehrsatz, Kirchlindach, Köniz, Mattstetten, Meikirch, Moosseedorf, Münchenbuchsee, Muri bei Bern, Ostermundigen, Stettlen, Urtenen-Schönbühl, Vechigen, Wiggiswil, Wohlen bei Bern, Worb, Zollikofen and Zuzwil.

The metropolitan region of Ottawa-Gatineau refers to the 'census metropolitan area' OttawaGatineau defined by Statistics Canada. This region includes the following 15 cities, townships and municipalities: Bowman, Cantley, Chelsea, Clarence-Rockland, Denholm, Gatineau, La Pêche, L'Ange-Gardien, Mayo, Notre-Dame-de-la-Salette, Ottawa, Pontiac, Russell, Val-desBois and Val-des-Monts.

The metropolitan region of The Hague is also known as Agglomeratie 's-Gravenhage and it refers to the COROP region (=NUTS NL332) defined by Statistics Netherlands (CBS). The metropolitan region includes the following six municipalities:'s-Gravenhage (The Hague), Leidschendam-Voorburg, Pijnacker-Nootdorp, Rijswijk, Wassenaar and Zoetermeer.

The metropolitan region of Washington, D.C. refers to the Washington-Arlington-Alexandria, DC-VA-MD-WV metropolitan statistical area (FIPS MSA Code 8840), which is delineated by the United States Office of Management and Budget (OMB). The metropolitan region includes the following 23 counties and cities plus the District of Columbia: Alexandria, Arlington, Calvert, Charles, Clarke, Culpeper, District of Columbia, Fairfax (city), Fairfax (county), Falls Church, Fauquier, Frederick, Fredericksburg, Jefferson, Loudoun, Manassas, Manassas Park, 
Montgomery, Prince George's, Prince William, Rappahannock, Spotsylvania, Stafford and Warren. 